\title{
Disability and Nitrogen Retention of Native Chicken Returns That Contain Bread Flour
}

\author{
Luh Suariani $^{1^{*}}$, Ni Ketut Etty Suwitari ${ }^{2}$, Ni Made Yudiastari ${ }^{3}$ \\ Universitas Warmadewa, Denpasar, Bali-Indonesia \\ \{aniekwidiarsa@ymail.com¹, ettysuwitary62@yahoo.co.id², mdyudiastari@yahoo.com³
}

\begin{abstract}
One of the alternative feed ingredients that can be used as a source of energy in rations and provides a good chance is bread waste flour from bread that has been rejected for less than 1 week, then the bread is withdrawn from the market. This bread can still be used because it has nutritional content, namely Crude Protein $6.47 \%$, Crude Fat $24.34 \%$, Crude Fiber 0.85, Ash $1.90 \%$ and Metabolic Energy $2952 \mathrm{Kcal} / \mathrm{kg}$. The principle of determining the digestibility of nutrients is to calculate the number of nutrients consumed minus the number of nutrients released through feces (Ranjhan, 1980). The design used in this study was a completely randomized design (CRD) with 5 (five) treatments and 3 (three) replications, namely $0 \%, 10 \%, 20 \%, 30 \%$ and $40 \%$. The provision of bread waste flour up to $30 \%$ can improve the digestibility of dry matter, organic matter, crude protein and Nitrogen retention of native chicken rations.
\end{abstract}

Keywords: Digestibility; Retention; Ration; Native Chicken

\section{Introduction}

Poultry farming, especially meat chickens, can generate very fast profits. This is because $52.6 \%$ of the need for female protein by the Indonesian people comes from poultry. In animal husbandry science, food is a part of environmental factors that need special attention, given that the cost of feed is $65 \%$ of the production cost [1]. Furthermore, it is said, $60 \%$ environmental factors, $30 \%$ climate and $10 \%$ management. The higher public awareness about the importance of nutrition causes the high consumption of animal protein.

Free-range chicken or native chicken is one of the local poultry that is generally kept by breeders in rural areas.Native chickens are reared as producers of consumption eggs, hatching eggs and meat. The maintenance of free-range chickens, apart from being able to be cultivated part-time, is easy to maintain with simple technology, and can be sold at any time for urgent needs [2], the native chicken farm has promising prospects, both economically and socially, because its products are in the form of meat and eggs. is a highly nutritious food material [3] and the demand is quite high [4].

One of the alternative feed ingredients that can be used as a source of energy in rations and provides a good chance is bread waste flour from bread that has been rejected for less than 1 week, then the bread is withdrawn from the market. The basic ingredients of bread are $90 \%$ wheat flour and other ingredients such as eggs, milk so that the protein content is high enough, besides that bread also contains beta carotene, thiamin (Vit B1), riboflavin (vitamin B2), niacin and the minerals iron and calcium (3) ]. The results of the proximate analysis of the 
Laboratory of Ruminant Nutrition and Animal Feed Chemistry, Faculty of Animal Husbandry UNPAD, bread waste flour contains $10.25 \%$ crude protein, $12.04 \%$ crude fiber, $13.42 \%$ crude fat, $0.07 \%$ calcium, $0.019 \%$ phosphorus, Water $6.91 \%$ and Ash $0.80 \%$ and Gross Energy 4217 $\mathrm{kcal} / \mathrm{kg}$. Seeing the metabolic energy content calculated from the Gross Energy, which is $2952 \mathrm{kcal} / \mathrm{kg}$, the bread waste flour can be used as an alternative feed material for energy sources, however its use in native chicken rations needs to be limited because it contains high crude fiber. Chickens have limited digestion of crude fiber due to the anatomical structure of the digestive tract, which has a small caecum. On this basis, the amount of crude fiber mixture in the ration must be limited to around $8 \%$. The use of bread flour as an energy source of 30 percent can contribute about 30 percent of the metabolic energy of the ration and if it is increased the use of bread waste to 50 percent will also increase the crude fiber content and this will disturb the performance of native chickens. High crude fiber can carry nutrients that can be digested from feed ingredients out with fees before being absorbed by the intestine. [6] The metabolic energy value of feed ingredients is the most applicable used in poultry as a basis for preparing rations. The principle of determining the digestibility of nutrients is to calculate the amount of food substances consumed minus the number of nutrients released through feces [7] [8]. Measurement of Nitrogen Retention in the ration aims to determine the quality of the ration given. High nitrogen retention will result in high growth as well, because the protein that is retained is greater.

The main factor that must be considered in the preparation of the ration is the crude protein content and energy, energy makes animals capable of doing a job and other production processes [6]. The metabolic energy value of feed ingredients is the most applicable used in poultry as a basis for ration preparation. The principle of determining nutrient digestibility is to calculate the amount of nutrients consumed minus the number of nutrients released through feces [8]. Measurement of Nitrogen Retention in the ration aims to determine the quality of the ration given. High nitrogen retention will result in high growth as well, because the protein that is retained is larger. Measurement of the digestibility value of a feed ingredient or ration can be carried out directly on poultry, namely free-range chickens, because native chickens have very fast growth and in a short time so that the optimal absorption of nutrients can be seen. Based on the description above, a study was conducted to measure the digestibility value of rations and $\mathrm{N}$ retention of native chicken rations containing bread flour.

\subsection{Formulation Of The Problem}

From the above circumstances, the problem can be formulated, namely

- How big is the effect of bread waste flour on the digestibility of native chicken rations

- How big is the retention of nitrogen rations containing bread waste flour.

\subsection{Research Purposes}

To study the effect of bread waste flour in the ration on its digestibility and nitrogen retention. In addition, it is also obtained to what extent this bread waste flour will produce a good ration for the growth of native chickens

\subsection{Research Urgency}

The ration is a determining factor for growth in addition to seedlings and maintenance management. The digestive system is a system consisting of the digestive tract and complementary organs that play a role in changing food materials both physically and chemically into nutrients that are readily absorbed by the walls of the digestive tract [9]. To 
spur growth, rations of sufficient quality and quantity are needed. The most important supporting factor for production in chickens is the digestibility of feed ingredients in the digestive tract such as energy digestibility, crude proteons and dry matter, measurement of digestibility and nitrogen retention is needed because these values minimize the low benefit of these feed ingredients, if the digestibility is low, the benefit value is low while vice versa.

\section{Method}

\subsection{Location and Length of Research}

The research on chicken rearing was carried out at Jalan Sedap Malam, while the analysis of digestibility and $\mathrm{N}$ retention was carried out at the Basic Science Laboratory, Faculty of Agriculture, Warmadewa University. The research will be carried out from April 2020 to July 2020.

\subsection{Research Methods}

The design used in this study was a completely randomized design (CRD) with 5 (five) treatments and 3 (three) replications. The treatments were as follows: R0 (ration without bread waste flour (TLR)), R1 (ration containing 10\% TLR, R2 (ration containing 20\% TLR), R3 (ration containing 35\% TLR) and R4 (ration containing 40\% TLR Chickens are given treatment starting at 3 weeks of age, and at 9 weeks of age, fecal collection is carried out. The composition of feed ingredients and composition of feed ingredients for treatment of native chickens 3 weeks old can be seen in Tables 1 and 2 .

Table 1. The composition of the ration material for the treatment of native chickens aged 3-10 weeks

\begin{tabular}{cccccc}
\hline \multirow{2}{*}{ Feed } & \multicolumn{5}{c}{ Ration } \\
\cline { 2 - 6 } & R0 & R1 & R2 & R3 & R4 \\
\hline Corn (\%) & 61 & 50,5 & 40 & 30 & 24 \\
Bread Waste Flour (\%) & 0 & 10 & 20 & 30 & 40 \\
Rice Brand(\%) & 12 & 11 & 11 & 10 & 5 \\
Fish Flour (\%) & 13 & 12,5 & 13,5 & 13,5 & 14 \\
Soybean meal (\%) & 12 & 13,5 & 13 & 13,5 & 14 \\
Coconut oil & 1 & 1,5 & 1,5 & 2 & 2 \\
Mineral & 1 & 1 & 1 & 1 & 1 \\
\hline Total & 100 & 100 & 100 & 100 & 100 \\
\hline
\end{tabular}

Source: Based on calculations Scott et al. (1982)

Information:

$\mathrm{R} 0=$ control ration without bread waste flour

$\mathrm{R} 1=$ rations containing $10 \%$ bread flour waste

$\mathrm{R} 2$ = rations containing $20 \%$ bread flour waste

$\mathrm{R} 3=$ rations containing $30 \%$ bread flour waste

$\mathrm{R} 4=$ rations containing $40 \%$ bread flour waste

The rations used in this study were rations that were mixed by themselves from milled corn, bran, soybean meal, fish meal, minerals and coconut oil and bread waste flour. Rations and drinking water were given adlibitum. The composition of feed ingredients and composition of feed substances for treatment of native chickens aged 3-10 weeks can be seen in Tables 1 and 2. 
Table 2. Composition of food substances rations treated by native chickens aged 3 - 10 weeks

\begin{tabular}{lcccccc}
\hline \multirow{2}{*}{ Nutrition } & \multicolumn{5}{c}{ Ration } & $\begin{array}{c}\text { Standar } \\
\text { Scoot1982 }\end{array}$ \\
\cline { 2 - 5 } & R0 & R1 & R2 & R3 & R4 & 17 \\
\hline Crude Protein (\%) & 18,56 & 18,63 & 18,54 & 18,41 & 18,38 & 2900 \\
Crude Fiber (\%) & 3,57 & 3,41 & 3,27 & 3,06 & 3,07 & 6 \\
EM (Kkal/kg) & 2995 & 2983 & 2943 & 2941 & 2979 & 10 \\
Fat (\%) & 5,22 & 5,22 & 5,22 & 5,22 & 5,21 & 0.9 \\
Ca (\%) & 1,55 & 1,54 & 1,54 & 1,54 & 1,54 & 0.4 \\
P & 0,76 & 0,76 & 0,76 & 0,76 & 0,76 & \\
\hline
\end{tabular}

Sources: NRC (1994) dan Scott et.al (1982)

\subsection{Materials and Tools}

Materials and tools used in this study were free-range chickens, cages and accessories, trays, plastics and scales, knives, paper and pens.

\subsection{Observed Variables}

The parameters observed were nitrogen retention, dry matter digestibility, protein digestibility and organic matter digestibility from the ration. Nitrogen retention parameters were taken based on the total collection method, namely the total collection of excreta was carried out for 3 consecutive days.

\subsection{Statistic Analysis}

The data obtained from the results of the study were analyzed for variance, if there were significant differences $(\mathrm{P}<0.05)$ between treatments, Duncan's multiple distance test was performed [10].

\section{Results And Discussion}

The digestibility of a substance according to [11] is the part that is absorbed in the digestive tract and is not excreted in the feces. Meanwhile, [12] stated that not all feed ingredients can be digested properly. The purpose of determining digestibility is to get a crude feed ingredient value, because only digestible feed ingredients can be absorbed. [11] stated that the low digestibility of a feed ingredient will result in a lot of energy being lost in the form of excreta, so that the metabolic energy value is low. Determination of digestibility in poultry is more complicated because feces and urine are mixed.

Digestion is a series of processes that occur in the digestive tract to allow the absorption of nutrients. The process starts from the physical changes in the feed, until finally there is a chemical change, so that finally the nutrients can be absorbed and can be used by livestock. Digestibility of feed ingredients or rations will be different influenced by species, physical form, composition of ingredients, level of feeding and environmental temperature [8]

From the analysis of variance, it was found that the use of bread waste flour as a substitute for corn in the ration had a very significant effect $(\mathrm{P}>0.01)$ on the digestibility of dry matter, organic matter, protein and nitrogen retention in native chicken rations (Table 3 ) 
Table 3. Effect of Treatment on Digestibility of Dry Matter, Crude Protein and Organic Materials and Nitrogen Retention of Native Chickens Ration

\begin{tabular}{cccccc}
\hline \multirow{2}{*}{ Para meter } & \multicolumn{5}{c}{ treatment } \\
\cline { 2 - 6 } & $\mathbf{R 0}$ & $\mathbf{R 1}$ & $\mathbf{R 2}$ & $\mathbf{R 3}$ & $\mathbf{R 4}$ \\
\hline $\begin{array}{c}\text { Dry matter } \\
\text { digestibility }\end{array}$ & $0,757 \mathrm{~b}$ & $0,792 \mathrm{a}$ & $0,800 \mathrm{a}$ & $0,802 \mathrm{a}$ & $0,803 \mathrm{a}$ \\
$\begin{array}{c}\text { Organiac Matter } \\
\text { Digestibility }\end{array}$ & $0,623 \mathrm{c}$ & $0,667 \mathrm{c}$ & $0,723 \mathrm{~b}$ & $0,768 \mathrm{a}$ & $0,755 \mathrm{a}$ \\
$\begin{array}{c}\text { Crude Protein } \\
\text { Digestibility }\end{array}$ & $0,578 \mathrm{c}$ & $0,686 \mathrm{~b}$ & $0,722 \mathrm{~b}$ & $0,761 \mathrm{a}$ & $0,714 \mathrm{~b}$ \\
Nitrogen Retention & $0,397 \mathrm{e}$ & $0,552 \mathrm{~d}$ & $0,603 \mathrm{~b}$ & $0,658 \mathrm{a}$ & $0,592 \mathrm{c}$ \\
\hline
\end{tabular}

Note: Letters that differ to the direction of the line indicate significant differences $(\mathrm{P}>0.01)$

\subsection{Dry Matter Digestibility}

From table 3 it can be seen that the effect of replacing corn with bread waste flour on native chicken rations increases the dry matter digestibility of native chicken rations $(\mathrm{P}>0.01)$. Dry matter digestibility increased significantly with the replacement of maize by bread waste flour, but there was no significant difference $(\mathrm{P}<0.05)$ at various levels of bread flour use. In the replacement of R3 and R4, the dry matter digestibility was higher than that of treatment R1 and R2 but it was not statistically significant. The lowest dry matter digestibility value is in the ration without bread waste flour, which is $75.7 \%$, while the highest is the use of bread waste flour $40 \%$ (R4) which is $80.3 \%$ and is statistically significantly different, the high dry matter digestibility is using bread waste is thought to be due to higher ration consumption. The high digestibility of dry matter is closely related to the amount of nutrient content that is absorbed. This is in line with the opinion [8] which explains that the type and quantity of carbohydrates in the ingredients or their addition to the ration reflects the digestibility of other food substances, especially with the increase in crude fiber content in the ration, the digestibility of other food substances will decrease. It is also stated that the high and low digestibility of food substances in the ration can be influenced by the rate of travel of food in the digestive tract and the content of food substances contained in the ration. Dry matter is a reflection of the amount of carbohydrates contained in the feed ingredients for the ration, because about 50 $80 \%$ of plant dry matter is composed of carbohydrates. In the proximate analysis, several cell wall components, such as hemicellulose, cellulose, and lignin, are included in the carbohydrate group (crude fiber and BETN), so that rations containing crude fiber are relatively different, so the dry matter digestibility is relatively different. Other factors thought to have influenced the dry matter digestibility of the rations were (1) the level of the proportion of feed ingredients in the ration; (2) chemical composition; (3) ration protein levels; (4) fat percentage; and (5) minerals. This is indicated by the data that the higher the lignin content obtained in the feces, the lower the value of the dry matter of the ration can be digested. In addition, differences in the value of digestible dry matter may be due to differences in the properties of the processed food, including its suitability for enzyme hydrolysis and the activity of substances present in the feed. Bread waste before it is made into a mixture of native chicken feed in this study is processed first. The bread waste obtained is dried in the sun, then crushed so that it gives a homogeneous mixture when mixed with other ingredients. This processing causes the components of the nutrient components to be simpler and easier to digest. This of course causes the speed of feed or the rate of digestion of feed in the digestive tract to become fast so that many nutrients are digested. Dry matter is a reflection of the amount of carbohydrates contained in the feed ingredients for the ration. The factors 
that affect the digestibility of dry matter, namely the amount of ration consumed, the rate of travel of food in the digestive tract and the type of nutritional content contained in the ration. Other factors that affect the dry matter digestibility value of the ration are the level of the proportion of feed ingredients in the ration, chemical composition, level of ration protein, percentage of fat and minerals. One part of the dry matter that is digested by microbes in the rumen is structural carbohydrates and non-structural carbohydrates [13].

\subsection{Organic Matter Digestibility}

From Table 3. It was seen that the effect of replacing corn with bread waste flour was significantly $(\mathrm{P}>0.01)$ able to increase the digestibility of organic matter in native chicken rations. The addition of waste flour in the ration can increase the digestibility of organic matter starting with the addition of bread waste by $20 \%$ (R2). The addition of $30 \%$ (R3) and $40 \%$ (R4) bread waste flour resulted in a significantly different treatment with treatments R0 $(0 \%), \mathrm{R} 1(10 \%)$ and R2 (20\%). The highest organic matter digestibility was obtained at $30 \%$ (R3) treatment of bread waste flour, although the results were not significantly different with the use of $40 \%$ (R4). The lowest digestibility value for organic matter was obtained on rations that did not use bread waste flour (R0), which was $62.3 \%$, while the highest was obtained for using bread waste flour $30 \%$ (R3), namely $76.8 \%$, and statistically significantly different (R> $0.01)$. Organic matter is dry matter that has been reduced by ash, a component of dry matter when fermented in the rumen will produce flying fatty acids which are a source of energy for livestock. The digestibility of organic matter in the digestive tract of livestock includes the digestibility of food substances in the form of organic material components such as carbohydrates, proteins, fats and vitamins. Organic materials contained in feed are available in insoluble form, therefore it is necessary to have a process of breaking these substances into soluble substances. The factors that affect the digestibility of organic matter are the crude fiber and mineral content of the feed ingredients. The digestibility of organic matter is closely related to the digestibility of dry matter, because most of the dry matter consists of organic matter. Decreased dry matter digestibility will result in decreased organic matter digestibility or vice versa [14]

This is in line with the principle of calculating organic matter from proximate analysis, where the lower the percentage of dry matter, the lower the percentage of organic matter will also be followed. In addition, the decrease in the digestibility value of organic matter may be caused by the high BETN content in the ration. [9], if the BETN content of the ration increases, the digestibility of organic matter will decrease. This is because most of the lignin is contained in BETN (compared to crude fiber of a feed ingredient), so that with the increase in BETN content, the digestibility of organic matter will decrease.

The nutrients needed by livestock depend on genetic variation, age, body weight, activity, ration energy content and environmental temperature [5]. Feed digestibility can be used as one way to assess a feed material [15]. The digestibility of the ration is influenced by the type of livestock, the type of ration material, the amount of ration and the nutrient content . Other factors that influence digestibility are temperature, rate of passage of the ration through digestion, physical form of the ration material and composition of the ration [6].

\subsection{Crude Protein Digestibility}

From Table 3 It was seen that the protein digestibility of native chicken rations using bread waste flour was significantly increased $(\mathrm{P}>0.01)$ compared to those that did not use bread waste flour. The highest crude protein digestibility was obtained in treatment R3 (30\%) which was $76.1 \%$ and the lowest was in treatment R0 $(0 \%)$ which was $57.8 \%$. The addition of bread 
waste flour will increase the digestibility of crude protein from native chicken rations. Bread waste consists of bread made from milk, flour, eggs, sugar and a little yeast, so that it tastes better. This better taste will result in increased palatability of chickens so that it will increase ration consumption and henceforth be able to increase the growth of livestock. Protein is an organic substance composed of elements of carbon, nitrogen, oxygen and hydrogen. Protein functions for basic living, new tissue growth, repair of damaged tissue, metabolism for energy and production [6]. The protein molecule is a polymer of amino acids combined in peptide bonds [16]. Crude protein digestibility depends on the protein content in the ration. Rations with low protein content generally have low digestibility and vice versa. The level of protein digestibility depends on the protein content of feed ingredients and the amount of protein that enters the digestive tract [16].

These results indicate that the digestibility value of Crude Protein is moderate to high after adding bread waste flour. This is in accordance with the opinion [6], that there are 3 categories of ration quality based on the level of digestibility, namely: digestibility values in the range of $50-60 \%$ are of low quality, between $60-70 \%$ of medium quality and above $70 \%$ of high quality. Poultry protein digestibility ranges from 70-85\% [5]. The use of bread waste flour $20 \%$ has been able to produce rations with crude protein digestibility above $70 \%$, which is $72.2 \%$, but it is only able to produce crude protein digestibility of $71.4 \%$ in R4 treatment (40\%). This is closely related to ration consumption, where the addition of $40 \%$ bread flour, the amount of consumption decreases because the energy in the ration increases. The decrease in feed consumption is thought to be caused by the high crude fat content in the bread flour waste, the higher the provision of bread waste flour, the higher the crude fat content in the treatment of hybrid broiler ducks. The high crude fat content causes the feed to spoil quickly and creates an unpleasant odor so that the palatability of livestock to feed decreases. One of the factors that influence the digestibility of crude protein is the protein content in the rations consumed by livestock, the composition of the feed and the physical form of the feed. Rations with low protein content generally have low digestibility and vice versa. The level of protein digestibility is influenced by the protein content of the ration and the amount of protein that enters the digestive tract [16]. [5] stated that the protein contained in excreta in addition to containing protein derived from undigested food, also comes from urine, basal metabolic waste, damaged epithelial cells, and enzymes carried by secretions. The amount of feces from chickens is influenced by the amount and type of ration consumed. The nutritional value content of treatment rations can be seen in Table 2. According to [5], ration consumption can be affected by quality, age, livestock activity, palatability, level of production and management. Poultry generally consume rations to meet energy needs, ration consumption will increase if the energy content of the ration decreases. [6] stated that birds can adjust their ration consumption to obtain sufficient energy for maximum growth. Meanwhile [17] stated that poultry tends to increase consumption when fed low energy feed. However, the results of the study did not show any significant difference with the provision of bread afkir at the $15 \%$ and $30 \%$ levels.

\subsection{Nitrogen Retention}

From Table 3 It was found that giving bread waste flour was significantly able to increase the nitrogen retention of native chickens. The highest nitrogen retention was obtained when using $30 \%$ of bread waste flour, which was $65.8 \%$, while the lowest was obtained in the treatment without using bread waste flour (R0), which was $39.7 \%$. Nitrogen retention is a method for assessing the quality of ration protein by measuring nitrogen consumption and nitrogen excretion in feces and urine so that the highest amount of nitrogen in the body can be 
found [18]. If the nitrogen consumed is greater than the excreted nitrogen, then the nitrogen retention value is positive, while the nitrogen retention is negative if the consumed nitrogen is smaller than the excreted nitrogen. The results of nitrogen retention in this study were positive. [19] stated that the more nitrogen retained was due, among other things, to the better digestion process and absorption of food substances, thereby accelerating the rate of passage. According to [11] that nitrogen retention depends on protein content in the ration. The nitrogen content retained was in line with the protein content of the ration. [5] stated that feed with low protein moves faster to leave the digestive tract than feed with high protein content, moves more slowly to leave the digestive tract to get more time for the denaturation and solution of the protein consumed. Nitrogen retention is influenced by several factors, namely: ration consumption, protein consumption and protein quality. Protein consumption and nitrogen retention are directly proportional. This retained nitrogen illustrates the efficiency of protein use in native chickens. Positive nitrogen retention means that the native chicken's body gains body weight due to increased muscle weaving.

For feed that contains bread flour, the ration is preferred (palatable) because bread flour gives a more fragrant aroma. Bread is made from milk, flour, eggs, sugar and yeast. The fermentation of the bread-making ingredients in the bread-making process will result in the feed ingredients being more easily digested, because the bonds have been broken when making bread. [5] stated that a higher nitrogen retention value means more nitrogen is left in the body so that less nitrogen is wasted along with excreta. Bread comes from wheat flour from milling wheat kernels. Wheat flour contains a lot of starch, which is a complex carbohydrate that is insoluble in water, it also contains protein in the form of gluten [20]. The bread waste used has a nutrient composition that is easy to digest. Bread is a food that is rich in starch, low in crude fiber and contains protein. Besides, it is also enriched with sugar, minerals and ingredients that can improve the quality of bread. [11] The bread waste used is the result of processing. Before being used, the bread waste is dried first and then finely ground. Processing causes the complex nutrient components to become simpler and easier to digest. According to [9], the simpler structure or shape of the particles causes the speed of feed or the rate of digestion of the feed in the digestive tract to become fast so that many nutrients are digested. Bread as human food is certainly safe for human consumption, does not contain toxins or antinutrients. Toxins and antinutrients will disrupt the metabolism in the body, including in the digestive process.

\section{Conclusion}

From the above discussion it can be concluded that giving bread waste flour can improve the digestibility of dry matter, organic matter, crude protein and nitrogen retention of native chicken. Giving bread waste flour as much as $30 \%$ is able to produce good quality rations where the digestibility of the crude protein is above $70 \%$. In preparing the native chicken ration, it is recommended to use bread waste flour of $20 \%$ to $40 \%$, to obtain good ration digestibility. 


\section{Reference}

[1]. M. Rasyaf, “Beternak Ayam Pedaging, Cetakan ke-24,” Jakarta: Penebar Swadaya, 2004.

[2]. R. Kartasudjana, and E. Suprijatna, “Manajemen Ternak Unggas,” Jakarta: Penebar Swadaya, 2005.

[3]. Widiastuti, and E. Sujana, "Pemanfaatan Tepung Limbah Roti dalam Ransum Ayam Ayam kampung dan Implementasinya terhadap Efisiensi Ransum," Seminar Nasional Fapet Unpad, 2009.

[4]. B. Bakrie, D. Andayani, M. Yanis and D. Zainudin, "Pengaruh penambahan jamu ke dalam air minum terhadap preferensi konsumen dan mutu karkas ayam buras," Seminar Nasional Teknologi Peternakan dan Veteriner. Puslitbang Peternakan, 2003.

[5]. J. Wahju, "Ilmu Nutrisi Unggas," Yogyakarta: Gadjah Mada University Press, 1997.

[6]. R. Anggorodi, “Ilmu Makanan Ternak Umum,” Jakarta: PT. Gramedia, 1994

[7]. A. Subhan, T. Yuwanta, and J. H. P. Sidadolog, "Pengaruh Kombinasi Sagu Kukus (Metroxylon Spp) dan Tepung Keong Mas (Pomacea Spp) sebagai Pengganti Jagung Kuning terhadap Penampilan Itik Jantan Alabio, Mojosari dan Hasil Persilangannya (The Effect of Steaming Sago (Metroxylon Spp) and Golden Snail Meal," Buletin Peternakan (Bulletin of Animal Science). vol. 34, no. 1, 2010.

[8]. S. K. Ranjhan, "Animal Nutrition In The Tropics," New Delhi: Vikas Publishing Hause P and T Ltd, 1980.

[9]. A. Parakasi, "Ilmu Gizi dan Makanan Ternak Monogastrik," Bandung: Angkasa, 1990.

[10]. R. G. D. Steel, and J. H. Torrie, "Prinsip dan prosedur suatu pendekatan biometrik. Terjemahan. Judul asli Principle and procedure of statistic a biometrical approach. Penerjamah Bambang S," Jakarta: PT. Gramedia, 1989.

[11]. P. McDonald, R. A. Edwards, J. F. D. Greenhalgh, C. A. Morgan, L. A. Sinclair, and R. G. Wilkinson, "Animal Nutrition. 7th Ed. Prentice Hall, Pearson, Harlow, England, London, New York, Boston, San Fransisco, Toronto, Sydney, Tokyo, Singapore, Hong Kong, Seoul, Taipei, New Delhi, Cape Town, Madrid," J. Zootek, vol. 37 , no. 1, pp.41- 49, 2010.

[12]. H. W. Titus, and J. C. Fritz, "The Scientific Feeding of Chickens. $5^{\text {th }}$ Ed," Illinois: The Interstate Printers \& Publishers, Inc. Danville, 1971.

[13]. Abun, D. Rusmana, N. P. Indriani, "Penentuan Kecernaan Ransum Mengandung Ampas Umbi Garut (Maranta Arundinacea Linn.) Pada Ayam Ayam Kampung Dengan Metode Pemotongan,” J. Bionatura, vol. 5, no. 3, pp. 227 - 238, 2003

[14]. S. E. Goal, L. Silitonga, and I. Yuanita, "Substitusi Ransum Jadi Dengan Tepung Limbah roti terhadap Performance Burung Puyuh (Cortunix Cortunix Japonica) Umur Starter," J. Ilmu Hewan Tropik, vol 4, no. 2, 2015.

[15]. Abun, "Pengukuran nilai kecernaan ransum yang mengandung limbah udang windu produksi produk fermentasi pada ayam petelur," Makalah Ilmiah. Universitas Padjadjaran, 2007.

[16]. T. Fransisca, J. S. Mandey, Y. H. S. Kowel, and M. N. Regar, "Nilai Retensi Nitrogen Dan Energi Metabolis Ayam Kampung Yang Diberi Ransum Tepung Limbah Sawi Putih (Brassica Rapa L. Subsp. Pekinensis)," J. Zootek, vol. 37, no. 1, pp.41-49, 2017. 
[17]. W. Widodo, "Nutrisi dan Pakan Unggas Kontekstual," Malang: Universitas Muhammadiyah Malang Press, 2002.

[18]. D. J. Farrell, "Effects Of Dietary Energyconcentration On Utilization Of Energy By Ayam Kampung Chickens And Body Composition Determined By Carcass Analysis And Predicted Using Tritium," British Poultry Science, vol. 15, no. 1, 1974.

[19]. G. G. Mateos, J. L. Sell, and J. A. Eastwood, "Rate Of Food Passage (Transit Time) As Influence By Level Supplemental Fat," Poultry Science.vol. 61, no. 1, pp.94$100,1982$.

[20]. D. P. Pusuma, Y. Praptiningsih, and M. Choiron, "Karakteristik Roti Tawar Kaya Serat Yang Disubstitusi Menggunakan Tepung Ampas Kelapa”. J. Agroteknologi, vol. 12, no. 1, pp.29-42, 2018. 